\title{
Three great books about power. Actual analysis of concepts
}

\author{
I.M. Zdretsov ${ }^{1}$, M.A. Vasilyeva ${ }^{2}$ \\ ${ }^{1}$ Department of Chemical Technology and Processing of Energy Carriers, Faculty of Mineral Raw \\ Materials Processing, Saint Petersburg Mining University, Saint Petersburg, Russia \\ ${ }^{2}$ Department of Philosophy, Faculty of Fundamental and Humanitarian Sciences, Saint Petersburg \\ Mining University, Saint Petersburg, Russia
}

\begin{abstract}
In this article, three books related to power were analyzed: Kitami Masao's "The Swordless Samurai”, Han Feitzu's "The Book of Law and Order" and N. Machiavelli's "The Prince". The main judgments were highlighted and conclusions were drawn on how each author understands the power. Similar and opposite conclusions were compared. Also, the reasons for the fundamental differences between these ideas are identified. Analysis of differences on a religious basis was made using the modern Agamben's work "The Kingdom and the Glory" as it touches on the relationship between religion and power. The study used an integrated cultural-philosophical approach, in which descriptive method, comparative analysis, and synthesis can be separated from each other. As a result of this work, the following conclusions were obtained: the difference in the functions of power leads to different understanding of power; the religious environment surrounding a person largely influences his understanding of power. Based on this, different concepts of power should be compared to identify common significant positions that demonstrate the nature of power relations.
\end{abstract}

\section{Introduction}

Robert Dahl said: "Power is when A has the influence over B to the extent that he can get B to do something B would not otherwise do" [1]. Reading these lines, you realize that power is an essential force. Everyone understands it in different ways; some say that power spoils a person; others believe that it is necessary to maintain order. The question of what kind of power should be must not be postponed for a long time. It should be asked as often as possible, because we live in an ever-changing world and in a state where our well-being depends on how the ruler uses power.

In this paper, we will turn to the thoughts of philosophers of the past, whose ideas, however, are reflected today. First of all, we will analyze the works of Machiavelli, Han Fei, and Kitami Masao, who in his book described the principles developed by the Japanese emperor Toyotomi Hideyoshi, and synthesize the obtained facts into conclusions about the understanding of the power of each of these thinkers. We will also draw parallels between their views; identify similarities and differences in concepts. It is important to understand that we will not compare whole ideas with each other in general, because due to the large 
differences, this will not make sense. On the contrary, we will compare the individual features of each idea identified as a result of analysis and synthesis. Besides, taking into account particular differences, we will identify the general reasons for these differences. The work of Giorgio Agamben "The Kingdom and glory" was chosen as a tool for analyzing some inconsistencies as it touches on the relationship between religion and power.This author is very popular nowadays, and the mentioned book was published recently. It means that the research will be most relevant.

"The Swordless Samurai", "The Book of Law and Order", "The Prince" are creations from different eras and corners of the world; for us, however, it is the concept of power itself that is important, not its temporal and territorial affiliation. Moreover, the authors of these works lived in different religious environments, which will help to tell whether there is a connection between religion and the understanding of power or not. The purpose of this work is not to say something completely new about power, but to describe existing concepts, consider the limits of their capabilities and internal contradictions. Although a large number of works have already been written about power in general, they do not directly relate to our topic. It is sufficient to study the above-mentioned works to accomplish the task.

\section{Analysis of works about power}

\subsection{Power as understood by Kitami Masao}

Japan was a closed country until the middle of the 19th century: the "bamboo curtain" collapsed only in 1854 after an agreement with the United States and the opening of ports [2]. After the abolition of the policy of isolation, Japan started the forced industrialization and modernization of the economy and it is now the most powerful industrial country in the world after the PRC and the United States [2]. The most prominent people in Japanese history, the samurais, played a significant role in this race. When the wearing of swords in public places was prohibited in 1857, and the soldier class was abolished, the former samurai began to use their philosophy in a different direction. They became successful entrepreneur's thanks largely dueto traditional military virtues of discipline, devotion, and fair play. Here it is worth referring to a character whose story every Japanese student knows: Toyotomi Hideyoshi. He is the benchmark of leadership in Japan. Kitami Masao's book, "The Swordless samurai," is devoted to his philosophy. First of all, we will analyze the ideas presented in it.

To start with, it is worth briefly describing the protagonist of the book. Hideyoshi was born in 1536 to a poor peasant family. He was small in stature, weak in build, uneducated, ugly, and, besides, he could not master the sword. Hideyoshi was born during the troubled "Century of Clan Struggles," when a military career was pretty much the only way to improve one's life. His modest physical attributes did not foresee success on the battlefield. Despite such deplorable initial conditions, this man, by his iron will, sharp mind, unyielding perseverance and keen understanding of human psychology, succeeded in uniting under his rule Japan torn by centuries of civil strife. He could become one of the most revered figures that every resident of the land of the rising sun now knows. Hideyoshiachieved such an incredible success thanks to his philosophy of leadership and the rules that a leader of a state or company must follow.

Hideyoshi decided to leave home at 15 . To survive, he had to constantly look for work. He took any job, became a vassal of the Matsushita clan, and rose higher and higher by excellently performing all the work assigned to him. This aspect of his life allowed him to formulate the rule"the secret of zeal: leaders should work more than others" [3]. 
"The secret of decisiveness: act boldly at critical moments" [3]. The word "boldly" in this context can be taken as a synonym for decisiveness. This conclusion was made based on the "secret of victory: start a battle only after you create the conditions for victory" [3]. The fact is that Hideyoshi seized power in Japan when he came up with a plan in which he took into account every variable. Thus, the outcome of the battle with its main rival had been predetermined even before the first drop of blood was shed. Fulfilling his plan, he acted decisively, and he explained his decisiveness by the fact that he was sure of a positive outcome of the battle. It follows that in a critical situation it is necessary to rely on the mind.

Once, a promise fulfilled brought the protagonist great success. After that, Hideyoshi realized that honesty should be the determining factor in his behavior; his efforts to attract allies were crowned with success again and again. Based on such a positive experience, the "secret of honesty" was formed: "keep promises" [3].

Hideyoshi often presented himself to distinguished people during his service. Even the minor achievements of the lower-ranking vassals did not go without his praise, and the rewards for significant successes exceeded all expectations. This encouraged his followers to try even harder. One of the vassals of the protagonist managed to notice in such behavior "the secret of approval: encourage people at every opportunity" [3].

Hideyoshi's closest adviser was a man named Hidenaga. One quality distinguished him from the other vassals: he did not hesitate to disagree with the protagonist, even on strategic issues. With such an adviser as Hidenaga, Hideyoshi built the strategically important fortress in Sunomata, successfully retreated during the rearguard battles against Kanegasaki, punished the traitor Mitsuhide, and resolved many other extremely important and dangerous situations. Thus, another rule of the leader emerges - "the secret of the counterbalance: seek advice from those who are not afraid to oppose it" [3].

Speaking of power, we have often applied the term "leadership" and fully disclosed its meaning. The leader, according to Kitami Masao, turned out to be the ideal possessor of power. Hideyoshi's mentor was Prince Nobunaga. He was a man who, like the protagonist, wanted to unite Japan, but he lacked a sense of tact and sovereign wisdom. His methods of achieving his goal were brute force and controlling people through fear. Hideyoshi relied on negotiation, diplomacy, and a subtle understanding of human psychology. The fact that he achieved his goal is proof of the superiority of his leadership's power over a style of power based on threats and force.

\subsection{Power as understood by Han Fei}

According to scientists, the age of Chinese civilization can be 5,000 years, which gives it the status of one of the oldest in the world [4]. In such a long time, Chinese thinkers managed to create a huge layer of knowledge about power. If you look at the history of China, you can see that for a long time some dynasties succeeded others, then as a result of the Xinhai revolution (1911-1913), the Chinese Republic was formed, the era of militarism began, and in 1949 the PRC began to exist as a socialist state [5]. Such facts create in the mind the image of tough power and a firm hand of the ruler. After reading "The Swordless Samurai", which preaches a different vision of power, this seems quite surprising, because China has largely influenced the culture of Japan [2]. To understand the reasons for the differences, first, you need to visualize them more accurately. For this purpose, let us turn to the work of Han Fei-Tzu (279-233 BC), "The Book of Law and Order", which reflects the idea of a despotic form of government. It became the basis of the political ideology of Qin Shi Huang, the ruler of the Kingdom of Qin (since 245 BC), who put an end to the twohundred-year era of Warring States [6]. By 221 BC, he was at the head of a single power 
throughout Inner China and went down in history as the creator and ruler of the first centralized Chinese state [6].

In the chapter "The Way of the Lord", Han Fei says that the ruler must possess impartiality and calm. He considers impartiality as the key to truth, the right decision, and tranquility is the key to seeing thesovereign as a model of action. If a subordinate sees the calmness of his sovereign, he will also calmly and accurately be able to execute his decision, because he is confident in its correctness. As a result, the governor, who can give the right instruction, and the official, who can fulfill it, areindisputably together the conditions for productive government. Thus, based on assertions of impartiality and equanimity, Han Fei draws the following conclusion: "If the words and actions turned out to be consistent with one another, the sovereign has no business then, for officials do everything" [7]. A similar state of affairs is used by the ruler to extract personal gain, to stay on top all the time. He makes wise to think and spend their mental resources, and then, choosing the best path, he acts without exhausting his wisdom. By following this pattern of behavior, the ruler always wins: "If there is merit, the sovereign falls into virtue, in the case of mistakes, the officials are blamed, then the glory of the ruler is not exhausted" [7]. Thus, the inaction of the lord is considered to be his advantage, and activity, based on the logic of the thinker, guides him down the path of error.

In the same chapter there is a rather interesting interpretation of bravery, which applies to rulers. The fact is that the sovereign while possessing wisdom, does not manifest it, he only directs officials to "true feelings", thereby forcing them to think and demonstratetheir abilities[7]. This is done so that the subordinates receive merit and become stronger and wiser. Besides, the sovereign learns that his subordinates can, and places everyone in their place according to their abilities, which creates the optimal conditions for achieving his goals. At this moment, his courage, that is, his abilities to assign duties to others, is evident: "Being brave, he restrains himself: he forces officials to show their military abilities" [7].

The last important detail that we can highlight in the chapter "The way of the Lord" was the attitude towards the awards. Completed orders must be rewarded, and failed orders must be punished, and the reward must be pleasant, "like a timely rain," and the punishment is menacing, "like thunder that neither spirits nor saints can understand" [7]. Also, the award must be public, and those punished cannot be pardoned. This is done so that capable people have an incentive to use their skills for the benefit of the sovereign, and unscrupulous officials and traitors no longer commit evil. From the chapter "Use of people": "If you establish a clear system of rewards and punishments, neither the official nor the robber will cause unrest" [7]. Also, in the chapter "Measure of the heart", the thinker argues that "the abundance of rewards is the basis of unrest" [7]. According to Han Fei, the degree of necessary cruelty in punishments is exhaustively demonstrated in the sentence: "If you punish strictly your loved ones, strangers and low officials will not become negligent, and the close people will not become proud" [7]. Thus, concerning punishments and rewards, Han Fei describes the ruler as if he were a machine that operates with variables according to an algorithm.

Next, we will list a few statements of the sage, which are combined as conclusions about the goals and means of the sovereign. They are all in different chapters. In the "Possession of the measure" Han Fei says: "... for those who can eliminate the personal and lawless and strive for the common good and the law, the people will be pacified down and the state will settle down" [7]. In the chapter "Signs of the possible death of the state", he describes what the ruler shall not do: "If you take the laws lightly ... If the sovereign loves palaces and terraces, arbors, lakes ... If you are voraciously self-seeking", etc.[7]. There are about fifty such "ifs". Generally speaking, this is something that cannot be done by a person who considers himself a highly spiritual being. It is also worth mentioning that "the people are calm when their duties are small" (chapter "Measures to ensure internal order") [7]. Let 
us analyze these statements. It is quite obvious here that the goal of the ruler is to preserve the state. To do this, one needs to drop hisdesires and act following the law, strive for the common good and the tranquility of the people. It can be assumed that such behavior is a means to an end. The fact is that Han Fei says nothing about the moral component of the ruler in isolation; he mentions the high moral qualities of the sovereign only in conjunction with the goal, that is, a calm, unbroken state. Thus, a successful sovereign must act for the good of the people, not himself and his family, regardless of whether he wants it or not. This is his professional duty, just as a doctor cures a patient, a janitor tidiesupa street, a lab assistantmakes an accurate analysis, etc. This attitude is best described by the words of Han Fei himself in the chapter "Measures to ensure internal order": "The carriage-maker, making carriages, wishes everyone to be rich and noble, while the coffin-maker, making coffins, wants people to die early ... the first has no humanity and the second has no evil intentions"[7]. Here everything determines the benefit to the cause. As a result, following the logic of the thinker, the state is a function of morality, and this function reaches its maximum (indestructible state) only if morality is a virtue (acting for the benefit of the people, observing of the law, eliminating of personal interests). Morality here becomes an attribute not of the person but the profession. Therefore, the emperor loses his human face because he cannot act as he wishes. Although he must act like a nobleman, as we understand it, hemust still do so, and he has no choice because otherwise, his state will fall. If the ruler gets in the way full of self-interest and pride, his possessions will someday fall, and, consequently, he will no longer rule, and will also no longer be the object of our reasoning.

When the word "ruler" appears in a conversation, we imagine a figure uttering some kind of speech or appeal. Indeed, we often see heads of modern states in the role of speakers, therefore, the ability to speak is one of the important aspects of a sovereign. In the chapter "Question of oratory", we are dealing with a dialogue between an unknown person and a philosopher, the object of which is dialectics. During the conversation, it turns out that the art of speaking arises as a result of "the unreasonableness of sovereigns" [7]. The fact is that when the orders and laws have no power, that is, when the sovereign is not able to make them real, he begins to look for all kinds of tricks, come up with new facts and choose words to encourage subordinates to carry out the planned projects. It turns out that the development of oratory is a sign of the cessation of legality. In the chapter "Signs of the possible death of the state" the same idea is expressed: "A state can fall ... if there is an art in speeches, but not the law" [7]. Summing up, the philosopher declares: "When the sovereign is unreasonable, skillful speeches arise" [7]. In other words, the ruler needs the art of speaking and coming up with tricks to make up for his mistakes, to make things right when something is wrong.

It is also worth mentioning the attitude towards subordinates as understood by Han Fei, he touched on this subject more than once. The sovereign places officials according to their abilities, avoiding themixing of duties. Then they easily do their job, perfecting themselves in one thing. As a result, they have no discontent, and thus there is no unrest in the state. At the same time, the thinker saysnothing about interpersonal relationships, and his subordinates seem to pieces on a chessboard. This state of affairs is best described by the words of Han Fei from the chapter "The Way of the sovereign": "Between the sovereign and the dignitaries there areno feelings binding father and sons; their relations are the result of the calculation" [7].

Talking about power, it is worth finding out whether to exalt the ruler, to make an idol of him, as happened, for example, in the USSR, where one personality cult replaced another (Plumper 2010). "The Book of Law and Order" contains little information on this issue. Han Fei in the chapter "Lord of the people" only says that the sovereigns subdue vassals for power and position, comparing these attributes with the strength of muscles [7]. 
Besides, the thinker argues that having lost his position, the sovereign becomes like a tiger and a panther, having lost teeth and claws - vulnerable and defenseless [7]. We have already said that the ruler should not be self-serving, it does not benefit him, therefore, he should not use his authority as a way to enrich himself. Thus, the influence of the ruler in the understanding of Han Fei is only a tool for the use of power.

Having analyzed some of the thoughts on power put forward by Han Fei in "The Book of Law and Order", we saw an image of an impartial ruler, cruel in his punishment and pleasant in rewards. For him, there are no friends or strangers; for him, there are only subordinates whose abilities he uses. He is noble, for he cannot be otherwise because of the possibility of losing the state. His behavior, character, and influence - all these are a tool to preserve the state. In other words, the ideal ruler here seems to be in the form of a machine that exists only to control the state. Not surprisingly, China now exists under socialism, which is usually characterized by a powerful and rigid state apparatus.

\subsection{Power asunderstoodbyMachiavelli}

When discussing power, it is impossible not to turn to the ideas of the Italian philosopher N. Machiavelli (1469-1527). His life took place in a dangerous era when the Pope had his army, and the rich independent city-states of Italy fell under the rule of foreign states France, Spain, or the Holy Roman Empire [8]. One of his most significant works is "The Prince". The ideas presented in this treatise complement well the views of Kitami Masao and Han Fei.

To begin with, we turn to chapter XVI, "About generosity and frugality”. Machiavelli says that it is good to have the glory of a generous ruler, but not to be generous: "... he who shows generosity to be generous harms himself" [9]. The point is that if the sovereign distributes rewards too lavishly, the treasury becomes empty. If the treasury is empty, it must be replenished, for which people are heavily taxed. Consequently, in the eyes of the people, such a ruler looks stingy, and because of this, discontent arises, which poses a threat to the state. Thus, it turns out that being generous to subordinates, the sovereign becomes mean to a wider circle of persons. Next, let's consider the reverse situation. Being stingy, the sovereign saves the treasury and, as a result, does not burden the people with excess taxes. Due to this, people consider him generous. In the authors' understanding, the generous sovereign here is the one who maintains a decent standard of living in the country. To do this, the ruler needs to be stingy with the nearest subordinates, that is, not to engage in their excessive enrichment. By having the flame of a generous ruler among the people, the sovereign thus gains theirsupport, and, therefore, protection from disgruntled subordinates who want more rewards. After all, it makes no sense to remove the ruler beloved by the people, because you will end up being an object of hatred and will not gain power anyway, and the state will fall. In the end, we can say that Machiavelli is saying here that clear rewards are needed for merit (stinginess), such that taxes are low (generosity). It turns out that the balance is in the economy.

In chapter XVII, "On cruelty and mercy and what is better: encouragement by love or fear", Machiavelli discusses the relationship between the ruler and subordinates. He says that love is unreliable because people can neglect it and use it against the sovereign. Fear, however, implies the threat of punishment, and it should not be neglected, since it will do no good, but harm. Here Machiavelli notes that love does not depend on the sovereign, each person can perceive his actions in his own way. Fear is created by the sovereign himself. As a result, Machiavelli concludes: "...a wise ruler is better of relying on what depends on him, and not on someone else" [9]. Furthermore, the philosopher also observes: “... it is only important not to incur the hatred of subordinates ..." [9]. We can say that in the modern conditions, fear is represented by the law, and love is represented by the generosity, which 
was mentioned above, such as the excessive enrichment of subjects. Thus, Machiavelli says that the sovereign must, with respect to his subordinates, rely primarily on the law.

Next, we turn to chapter XVIII, "About how sovereigns should keep their word". At first, Machiavelli says that honesty in a sovereign is meritorious, but after notices that only those who could deceive were successful. According to the philosopher, those in power should "if possible, not depart from good, but if necessary, not shy away from evil"[9]. It turns out that good ("mercy, loyalty, straightforwardness, humanity, and gratefulness) is necessary for the sovereign only to maintain his image, so that others do not refuse to deal with him, and evil, that is, falsehood, to achieve goals if the situation requires it. As an example, the thinker cites the fact that many peace treaties were broken by deception, and the one who lied was always the victor. This, however, is obvious, because it makes no sense to deceive if you do not benefit from this. The sovereign needs to deceit to achieve his goal, that is, to preserve the state. It is not a question of preserving the individual. Deception, according to Machiavelli, seems to be the condition in which the ruler must work.

In chapter XXI, "What the sovereignshould do, to be honored", Machiavelli says that the ruler must act for the good of the citizens so that in each of his actions they see greatness. It is more interesting to note here why the veneration of the sovereign is necessary. The philosopher talks about Ferdinand Aragon, who carried out one military campaign after another, thereby causing admiration among his subjects. As it turned out, this admiration was necessary to maintain power: "So he thought over and carried out great plans, keeping in constant admiration and tension the subordinates who absorbedly followed the course of events... there was no time to conceive anything against the sovereign" [9].

The word fearlessness appears in the same chapter. Here it is used as the synonym of decisiveness. For example, Machiavelli says that a fearless sovereign must side with of oneof the belligerents. But he does not do this thoughtlessly, but with the expectation that he will win in any case. If the ally wins, he will be obliged to the sovereign; if he loses, he will help, as a brother in adversity.

Now we turn to chapter XXII “Aboutsovereign's advisers". Machiavelli believes that the ruler's adviser should care about the sovereign more than about himself. The thinker also distinguishes three kinds of mind: "one comprehends everything himself; another can understand what the first comprehended; the thirddoes not comprehend anything by himself and cannot understand anything comprehended by others"[9]. He calls the first one "outstanding", the second - "significant", and the third - "unfit" [9]. If Machiavelli believes that the first mind is outstanding,then such a mind should be present in the adviser. Such an adviser will be able to come up with something different from the sovereign's ideas, and if the sovereign's thoughts turn out to be wrong, the adviser can do him a great service.

As a result, power,as understoodby Machiavelli can be characterized as a prudent management to preserve the state. Here everything is done for the benefit, whether generosity or fear. Even fearlessness conceals calculation. Honoring the sovereign is an instrument of maintaining his power.

\section{Comparison of the concepts of power}

\subsection{The concepts of power and leadership}

In the works of Kitami Masao, Han Fei, and Machiavelli we found several similar positions. All three texts said that the ruler should be decisive. This feature has been named 
everywhere in different ways: boldness in "The Swordless Samurai", bravery in "The Book of Law and Order", fearlessness in "The Prince". All three thinker simplydecisiveness as a willingness to act, based on the clear understanding that everything goes according to plan, and victory or profit was inevitable. Thus, only a person who can think ahead of his actions can use power. Another similarity has been seen in the figure of the adviser described in "The SwordlessSamurai" and in "The Prince". Kitami Masao writes that an adviser should be a person who can object. In the text of Machiavelli, the same idea can be traced, since he considers an outstandingmind capable of comprehending everything.

Speaking about Kitami Masao's book "The Swordless Samurai”, concerning power, we mainly used the word leadership. Exploring the works of Machiavelli and Han Fei, this term was not used. At the same time, the ideas with which Hideyoshi lived differed significantly from the conclusions of "The Prince" and "The Book of Law and Order", while the latter two works are not much different. This gives us the right to assume that the essence of the differences lies in the word leadership.

"The secret of zeal", tells us that the leader works harder than others. However, Han Fei says that the ruler should have no business, and inaction is his advantage. Here the essence of the difference lies in the fact that the leader works with everyone, he is as if equal to his subordinates. Power as understood by Han Fei, on the contrary, implies the use of subordinates, placing them according to their capabilities. By observing their actions, the sovereign finds the right solution. Thus, the leader can be compared to a commander who himself participates in the battle, and the sovereign in the understanding of Han Feito a chess player who only rearranges the pieces on the board.

Kitami Masao writes that honesty is one of the main features of a leader's power. Promises must be kept, as this draws allies to his side. Machiavelli, on the other hand, believes that the sovereign can either fulfill a promise or break it if necessary. Here the difference lies in the purpose. Hideyoshihad no state; he defended the honor of the clan so that later he could find allies and unite Japan. The sole task of the sovereign asunderstood byMachiavelli, is to preserve the state. Thus, the leader tries to maintain the image, and Machiavelli's ruler tries to save the state, with the result that one cannot lie, and the other must if the situation demands it.

Another important difference was the attitude towards the rewards. Hideyoshi bestowed excellence at the earliest opportunity, even for the smallest merit. Han Fei believed that the reward system should be established. Machiavelli wrote the same thing, calling it stinginess. The leader's task is to lead the people. He cares about stimulating subordinates, and not about maintaining the standard of living of the people. For the ruler, however, it is necessary to preserve the state and, therefore, to be successful in this, he should not squander the treasury on his subordinates and thereby trouble hispeople.

Having gathered all our arguments together, we can conclude that leadership and power are completely different things. The leader must lead the people, and the ruler must preserve the state. Different approaches are used to fulfill these functions, oftenat odds with each other. Thus, to use power, to be a ruler, it is not necessary to become a leader, you need to be a person who, depending on the situation, can use that power correctly, that is, make a decision that does not entail the death of the state.

\subsection{Religion and perceptions of power}

Having sorted out the differences associated with the definition of leadership it is worth finding out if there were any other significant reasons for the different understandings of power. To answer this question, let us first recall what the veneration of the ruler is for and whether it is necessary at all in the opinion of Machiavelli, Han Fei, and Kitami Masao. In 
the book "The Prince", the philosopher writes that the ruler should arouse admiration among his subordinates so that they do not have time to think about the overthrow of the ruler. Han Fei also believes that the sovereign needs authority and position since they are his "muscles", that is, an instrument for exercising power. A different opinion is demonstrated in the book "The Swordless Samurai", where this topic is not touched on at all, and the protagonist throughout the whole story is perceived as equal to his subordinates. That is, admiration for the ruler there is not considered something important and worthy of mention. To explain this difference, we turn to Giorgio Agamben's contemporary work, "The Kingdom and the Glory".

In the chapter "The power and the glory", Agamben refers to the thesis of the theologian Peterson, devoted to the relationship between political and church ceremonies. The link is established in the text by the example of the concept of acclamation:"an exclamation of approval, glee, encouragement or disagreement shouted by the crowd in certain circumstances"[10]. It is mentioned that "... acclamation could be addressed to the magistrates of the republic, and later to the emperor. On the occasion of the monarch's arrival in the city, a ceremonial procession was organized, which was usually accompanied by solemn acclamations"[10]. This description is just like the admiration and reverence for the ruler mentioned above. Further, Agamben also referring to the works of other authors, writes that political acclamations are similar to Christian liturgies, laudatory songs, and prayers: "The Liturgy and oikonomia (managing people) are in this sense closely interconnected, as in chants and laudatory acclamations, and actions performed by a priest always and exclusively "expressing the Savior's economy" [10]. By "Savior's economy" is meant here how God controls people. Given the similarities between religious and state rituals discovered by J. Agamben, we can assume that religion affects one's understanding of power.

Using the conclusion derived from the work of Giorgio Agamben, we can analyze the significance of admiration for the ruler in the three texts discussed above from a new perspective. In fifteenth-century Italy, the Catholic Church played a major role, so Machiavelli's view that the ruler should arouse admiration among his subordinates may have been formed under its influence, because church ceremonies are also a kind of veneration not of the sovereign but God. Han Fei's teacher was the leading Confucianist of the time,Xun-Tzu. In Confucianism, two concepts are of interest to us: "xiao" - reverence for parents, diligent service to parents, etc., and "tee" - respect for older brothers, respect for elders [11]. Besides, the state was identified with society, and social ties with relationships in the family[11]. It can be assumed that the ruler is a senior who should be honored. Thus, this corresponds to the fact that in "The Book of Law and Order" authority and position are necessary to the sovereign. From the 8 th -12 th century BC to date, Shintoism is the religion in Japan [12]. It consists of the deification of nature; it is believed that everything has its spiritual essence [12]. There is also worship here, but this is the worship of various spirits. Moreover, the main principle of Shinto is to live in harmony with man and nature, and worship is no longer as important, as consent [12]. In the end, this may explain the lack of thoughts about praising the leader in "The Swordless Samurai".

Based on the work of Giorgio Agamben, we hypothesized that religion greatly influences perceptions of power. By correlating the views on the reverence of the ruler of the three philosophers with the religions that prevailed in their country, we confirmed our assumption. Thus, the difference in views on power is also caused by the religious environment thatsurrounds the individual. 


\section{Conclusion}

In this paper, we studied the works of three thinkers. Kitami Masao in "The Swordless Samurai" talks about the power of a leader, a man who leads people. Han Fei and Machiavelli in their works describe a ruler who uses power for one purpose only:to conserve the state. In "The Book of Law and Order," the sovereign is shown as a machine acting according to a certain algorithm, since the possession of power obliges him to behave in this way. Otherwise, he might lose his power, and, as a consequence, lose the state. Thus, power here is responsibility. In "The Prince", the ruler is shown as a prudent man who seeks profit everywhere, who does not hesitate to deceive or hold in fear his subordinates. As a result, as understood by Machiavelli, power is the right to act as required by the state.

It can be argued that there are a large number of fundamental differences between the leader's power, presented in "The Swordless Samurai," and the other two, characterized in "The Book of Law and Order"and "The Prince" (let it be the power of the sovereign): attitude to action and inaction (the leader works more than others, and the sovereign is inactive), to subordinates (the leader is equal to subordinates, and for the sovereign they are pawns), to rewards (the leader is generous, and the sovereign is stingy), and to lies (the leader keeps a promise, and the sovereign deceives if it is necessary). On the one hand, these differences arise because the leader maintains the image, and the sovereign saves the state. Thus, the difference in the functions of power causes its different understanding.

On the other hand, the ideas of the modern philosopher Giorgio Agamben from the book "The Kingdom and the Glory" give grounds to believe that the religious environment surrounding a person has a great influence on his understanding of power. As a result, where worship of God or ancestors is important, there is also a worship of the sovereign. Where the main issue is the harmony of man and nature, and worship goes by the wayside, it is also irrelevant to the sovereign. This influence of traditional religious views can be traced in the presented concepts of power and gives grounds to see them as an extension, an organic part of the cultural system, and not a separate construct.

\section{References}

1. R. Dahl, The Concept of Power. In Behavioral Science, 2, 201-205(1957)

2. V. Eliseeff, The Japanese Civilization,(Moscow: ACT, 2008)

3. M. Kitami, The Swordless Samurai, (Minsk: Popurri,2018)

4. L. Li, The Chinese Neolithic: Trajectories to Early States.(Cambridge: Cambridge University Press, 2005)

5. A. Saidov, National Parliaments of the World, (Moscow: Volters Kluver, 2005)

6. L. Vasilev, Ancient China. Volume 3: the Zhanguo Period (V - III centuries BC),(Moscow: Vostochnaya Literatura, 2006)

7. F. Han, The Book of Low and Order. Advice to a Reasonable Ruler, (Moscow: Centropoligraf, 2019)

8. N. Kapponi, Machiavelli: The Genius of Political Intrigue,(Moscow: Veche,2012)

9. N. Machiavelli, The Prince, (Moscow: Ripol Klassik, 2019) 
10. G. Agamben, The Kingdom and the Glory,(St. Petersburg: Izdatelstvo Instituta Gajda$\mathrm{ra}, 2018)$

11. L. Perelomov, Confucius and Confucianism from antiquity to the present,(Moscow: Stilservis, 2009)

12. W. WoodardShintoism: Ancient Religion of Japan, (Moscow: Sofiya, 2007). 